\title{
A Study on Resource Use Efficiency and Cost and Return of Sugarcane Cultivation in Sultanpur District of Eastern Uttar Pradesh
}

\author{
Avinash Mishra*, R. R. Kushwaha and Praharsh Singh
}

Department of Agricultural Economics, Acharya Narendra Deva University of Agriculture and Technology, Kumarganj, Ayodhya (U.P.), India

*Corresponding author

Keywords

Cost, Cropping

Intensity, Gross

Income, Net

Income, Input

Output Ratio,

Returns to Scale

Article Info

Accepted:

20 December 2020

Available Online:

10 January 2021
Hundred sample farmers (Marginal- 60, Small- 25, and Medium- 15) were interview from five villages of Kurebhar block of Sultanpur district. Data hence gathered was analyzed and it was found that average holding size was 1.71 hectares and cropping intensity was 182.46 per cent. On an average cost of cultivation was $\square 92691.29$ per hectare. The gross and net incomes on overall farms were found to be $\square 191544.53$ and $\square 105083.49$ per hectare, respectively. The input and output ratio was found to be 1:2.06 on cost C. sugarcane cultivation in the study was characterized by decreasing return to scale.

\section{Introduction}

Sugarcane (Saccharum officinarum L.) belongs to family gramineae and originated to tropical south Asia and south east- Asia. Sugarcane is a renewable, natural agriculture resource because it provides sugar besides biofuel, fibre, fertilizer and myriad of byproducts with ecological sustainability. Sugarcane juice is used for making white sugar, brown sugar (Khandhasari), jaggery (Gur) and ethanol.

Sugarcane is an important cash crop grown in
India. Sugarcane cultivation and development of sugar industry runs parallel to the growth of human civilization and is as old as agriculture. The importance and use of sugarcane and sugar in the country's socioeconomic milieu is deep rooted and immense. In the current day rural economy set up sugarcane cultivation and sugar industry has been focal point for socio-economic development in rural areas by mobilizing rural resources generating employment and higher income, transport and communication facilities. About 7 million sugarcane farmers and large number of agricultural labourers are 
involved in sugarcane cultivation and ancillary activities. Apart from this the sugar industry provides employment to 5 Lakh skilled and semiskilled workers in rural area. "Statistical yearbook"; Food and Agricultural Organization, 2015.

Nearly 1877.10 million tonnes of sugarcane was produced in the harvesting year 2017-18 worldwide. With the production of over 739.27 million tonnes in 2017-18, Brazil was the leader in Sugarcane production followed by India (341.20 million tonnes) and China (125.54 million tonnes). (Food and Agriculture Organization Corporate Statistical Database, 2018)

The information regarding the area, production and productivity of Sugarcane cultivationin Uttar Pradesh shows that the highest area under sugarcane cultivation in Uttar Pradesh was 23.40 lakh hectares in the year 2018-19 and the lowest area under cultivation was 19.77 lakh hectares in the year 2009-10. The highest production of sugarcane was in the year 2018-19 i.e. 1753.5 lakh tonnes and the lowest production was in the year 2009-10 i.e. 1171.4 lakh tonnes. The maximum yield was obtained in the year 2018-19 which was 74.93 tonnes/ha and the minimum yield was in the year 2010-11 which was 56.73 tonnes/ha. (Department of Agricultural and Farmers Welfare. $3^{\text {rd }}$ Advance Estimates for Sugar Season 201718. March 2018, Vol.49, No.7.)

\section{Materials and Methods}

\section{Selection of sample farmers}

A separate list of sugarcane growers of five selected villages were prepared along with their size holding and classified into three categories i.e. (1) Marginal farmer (below 1 hectare), (2) Small farmer (1-2 hectare) and (3) Medium farmer (2-4 hectare). Multistage stratified cum random sampling technique was used to select the district, block, village and farmers. Sultanpur district was selected purposely. A list of all the blocks was prepared and Kurebharblock was selected purposively.

\section{Method of enquiry}

The primary data were collected by survey method through personal interview on wellstructured schedule, while secondary data were collected from books, journals, report and records of the district and block headquarters (Land acreage in Sultanpur district is four bigha per hectare).

\section{Analytical tools}

Both the tabular and functional analysis were used. Weighted average was worked out for interpretation of data with the help of following formula.

$W A=\frac{\sum W_{i} X_{i}}{\sum W_{i}}$

Where,

$\mathrm{WA}=$ Weighted Average

$\mathrm{Xi}=$ Variable

$\mathrm{Wi}=$ Weights of variable

\section{Production function}

To study the resource use efficiency in sugarcane production, Cobb-Douglas production function was used. The mathematical form of Cobb Douglas production function is:

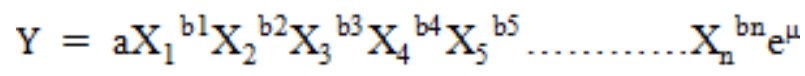

Where,

$\mathrm{Y}=$ per hectare output $(\square / \mathrm{ha})$ 
$\mathrm{X}_{1}=\operatorname{seed}(\square / \mathrm{ha})$

$\mathrm{X}_{2}=$ Irrigation charge $(\square / \mathrm{ha})$

$\mathrm{X}_{3}=$ Plant protection charges $(\square / \mathrm{ha})$

$\mathrm{X}_{4}=$ Manure and fertilizers $(\square / \mathrm{ha})$

$\mathrm{X}_{5}=$ Labour Cost $(\square / \mathrm{ha})$

$b_{i}=$ Elasticity coefficient of the respective input variables

$\mathrm{e}=$ Error term or disturbance term

$\mu=$ Random variables

\section{Results and Discussion}

\section{Cost and Returns}

The different cost concepts viz. Cost A1/A2, B1, B2, C1, C2 and C3 were considered for analysis of the data. On an average cost $A_{1} / A_{2}$, cost $B_{1}$, cost $B_{1}$, cost $C_{1}$, cost $C_{2}$ and cost $\mathrm{C}_{3}$ came to $\square 64288.31, \square 68601.86$, $\square$ 78619.86, $\square$ 52531.47, $\square$ 84262.80, $\square$ 92691.29, respectively.

On an average gross income was recorded $\square$ 191544.33 and net income came to $\square$ 105083.49. On medium farms, gross income was highest, which was recorded $\square$ 192000.00, followed by marginal farms $\square 191804.33$ and lowest on small farms $\square$, 190829.27, respectively. The net income was highest on marginal farms $\square \quad 105886.69$ followed by medium farms $\square 105604.43$ and small farms $\square 103759.37$.

On an average family labour income, farm business income and farm investment income were observed to $\square$ 112942.673, $\square 8822.89$ and $\square 84926.61$, respectively. Family labour income was highest on marginal farms followed by medium and small farms, farm investment income was highest on medium farms followed by small farms and marginal farms and farm business income was highest on marginal farms followed by medium farms and small farms. On an average, yield per hectare was estimated 598.57 quintal. The benefit cost ratio for marginal, small and medium farmers were observed to be $1: 1.10$, $1: 1.13$ and $1: 1.17$, respectively. On an average benefit cost ratio were observed to be $1: 1.13$.

On an average input output ratio regarding costs $\mathrm{C}_{3}, \mathrm{C}_{2}, \mathrm{C}_{1}, \mathrm{~B}_{2}, \mathrm{~B}_{1}$, and $\mathrm{A}_{2} / \mathrm{A}_{1}$ were recorded 1:2.06,1:2.27, 1;2.57, 1:2.43, 1:2.78 and 1:2.97, respectively. On the basis of cost $\mathrm{C}_{3}$ input output ratio was highest on medium farms (1:2.11) followed by small farms (1:2.08) and marginal farms (1:2.01), respectively. It may be concluded the cost of cultivation on different size group of farm increases with an increase in farm size. But net return per hectare was found of negative trend with farm size. It was because of less increase in yield against the increased input factors at increasing size of farm. Per hectare cost of return from the cultivation of sugarcane crop on different categories of farms have been presented in Table 1.

\section{Resource use efficiency}

The Cobb - Douglas production function was applied to find out the efficiency of various resources use in production of sugarcane. It indicated that five variables viz. seed, irrigation, plant protection chemicals, fertilizer and labour.

In marginal household the production elasticity's of seed, irrigation, plant protection chemicals, fertilizer and labour were 0.01 , $0.06,0.44,0.24$ and 0.63 , respectively. The return to scale in marginal farm was 0.97 which shows decreasing return to scale i.e. marginal farmers were gaining less than what they were spending. The $\mathrm{R}^{2}$ value of marginal household was 0.90 i.e. the considered variable explains 90.00 percent of the variation in depending variable i.e. return from sugarcane. It can be concluded that cost of fertilizer at 5 percent level of significance had significant influence on the returns. 
In small household the production elasticity's of seed, irrigation, plant protection chemicals, fertilizer and labour were $0.10,0.20,0.25$, 0.07 and 0.47 , respectively. The return to scale in small farm was 1.09 which shows increasing return to scale i.e. small farmers were gaining more than what they were spending. The $\mathrm{R}^{2}$ value of small household was 0.93 i.e. the considered variable explains 93.00 percent of the variation in depending variable i.e. return from sugarcane. The cost of seed at 5 percent level of significance and cost of irrigation at 1 percent level of significance had significant influence at the returns from sugarcane
In medium household the production elasticity's of seed, irrigation, plant protection chemicals, fertilizer and labour were 0.30 , $0.44,0.11,0.23$ and 0.02 , respectively. The return to scale in medium farm was 1.10 which shows increasing return to scale i.e. medium farmers were gaining more than what they were spending. The $\mathrm{R}^{2}$ value of medium household was 0.95 i.e. the considered variable explains 95.00 percent of the variation in depending variable i.e. return from sugarcane. It was found that the cost of seed at 5 percent level of significance and cost of irrigation at 1 percent level of significance had significant influence at the returns from sugarcane.

Table.1 Measures of Per Hectare Cost and Return of Sugarcane (Rs.)

\begin{tabular}{|c|c|c|c|c|c|}
\hline \multirow{2}{*}{ Sl. No. } & Particulars & \multicolumn{3}{|c|}{ Size group of farms } & \multirow{2}{*}{ All farm average } \\
\cline { 3 - 5 } & & Marginal & Small & Medium & \\
\hline 1. & Cost $\mathrm{A}_{1} / \mathrm{A}_{2}$ & 63849.38 & 64793.99 & 64221.56 & 64288.31 \\
\hline 2. & Cost $\mathrm{B}_{1}$ & 68106.94 & 69154.48 & 68544.16 & 68601.86 \\
\hline 3. & Cost $\mathrm{B}_{2}$ & 78106.94 & 79154.48 & 78544.16 & 78619.86 \\
\hline 4. & Cost $\mathrm{C}_{1}$ & 77102.61 & 73247.65 & 72444.16 & 52531.47 \\
\hline 5. & Cost $\mathrm{C}_{2}$ & 87102.61 & 83247.65 & 82444.16 & 84264.80 \\
\hline 6. & Cost $\mathrm{C}_{3}$ & 95812.87 & 91572.42 & 90688.58 & 92691.29 \\
\hline 7. & Gross income & 191804.33 & 190829.27 & 192000.00 & 191544.53 \\
\hline $\mathbf{8 .}$ & Net income & 105886.69 & 103759.37 & 105604.43 & 105083.49 \\
\hline $\mathbf{9 .}$ & Family labour income & 113697.39 & $111,674.79$ & 113455.84 & 112942.673 \\
\hline $\mathbf{1 0 .}$ & Farm business income & 127954.95 & 126035.28 & 127778.44 & 88922.89 \\
\hline 11. & Farm investment income & 118959.28 & 121942.11 & 123878.44 & 84926.61 \\
\hline 12. & Yield (q/ha) & 599.39 & 596.34 & 600.00 & 598.57 \\
\hline 13. & Benefit-Cost ratio & $1: 1.10$ & $1: 1.13$ & $1: 1.17$ & $1: 1.13$ \\
\hline 14. & Input- output ratio & & & & \\
\hline (i) & On the basis of $\mathrm{C}_{3}$ & $1: 2.01$ & $1: 2.08$ & $1: 2.11$ & $1: 2.06$ \\
\hline (ii) & On the basis of $\mathrm{C}_{2}$ & $1: 2.20$ & $1: 2.29$ & $1: 2.32$ & $1: 2.27$ \\
\hline (iii) & On the basis of $\mathrm{C}_{1}$ & $1: 2.48$ & $1: 2.60$ & $1: 2.65$ & $1: 2.57$ \\
\hline (iv) & On the basis of $\mathrm{B}_{2}$ & $1: 2.45$ & $1: 2.41$ & $1: 2.44$ & $1: 2.43$ \\
\hline (v) & On the basis of $\mathrm{B}_{1}$ & $1: 2.81$ & $1: 2.75$ & $1: 2.80$ & $1: 2.78$ \\
\hline (vi) & On the basis of $\mathrm{A}_{1} / \mathrm{A}_{2}$ & $1: 3.00$ & $1: 2.94$ & $1: 2.98$ & $1: 2.97$ \\
\hline & & & & \\
\hline
\end{tabular}


Table.2 Resource use Efficiency in Sugarcane on Different Size of Sample Farms

\begin{tabular}{|c|c|c|c|c|c|c|c|}
\hline \multirow{2}{*}{$\begin{array}{c}\text { Size group of sample farms } \\
\text { (ha) }\end{array}$} & \multicolumn{5}{|c|}{ Production elasticities } & \multirow{2}{*}{$\begin{array}{c}\text { Returns to } \\
\text { Scale }\end{array}$} & \multirow{2}{*}{$\mathbf{R}^{\mathbf{2}}$} \\
\cline { 2 - 9 } & $\mathbf{X}_{\mathbf{1}}$ & $\mathbf{X}_{\mathbf{2}}$ & $\mathbf{X}_{\mathbf{3}}$ & $\mathbf{X}_{\mathbf{4}}$ & $\mathrm{X}_{5}$ & \\
\hline Marginal & 0.01 & 0.06 & 0.44 & $0.24^{* *}$ & 0.63 & 0.97 & 0.90 \\
& $(0.01)$ & $(0.05)$ & $(0.25)$ & $(0.10)$ & $(0.33)$ & & \\
\hline Small & $0.10^{* *}$ & $0.20^{*}$ & 0.25 & 0.07 & 0.47 & 1.09 & 0.93 \\
& $(0.01)$ & $(0.06)$ & $(0.20)$ & $(0.05)$ & $(0.28)$ & & \\
\hline Medium & $0.30^{* *}$ & $0.44^{*}$ & 0.11 & 0.23 & 0.02 & 1.10 & 0.95 \\
& $(0.11)$ & $(0.11)$ & $(0.08)$ & $(1.3)$ & $(0.02)$ & & \\
\hline
\end{tabular}

**significant at $5 \%$ significance level

* significance at $1 \%$ significance level

Where,

$\mathrm{X}_{1}, \mathrm{X}_{2}, \mathrm{X}_{3}, \mathrm{X}_{4}$ and $\mathrm{X}_{5}$ stand for seed, irrigation, plant protection chemicals, fertilizers and labour cost $(\square)$ respectively

Cost estimation revealed that indicate that cost of cultivation, was highest on small farms ( $\square$ 87069.00), followed by medium farms $(\square$ 86395.57) and small frms ( $\square$ 85917.64), respectively. The overall average costs of cultivation was observed ( $\square$ 86476.72) on sample farms.

The major component of the cost were human labour (15.61 percent), machinery charges (7.09 percent), manure and fertilizer (9.22 percent), recent value of owned land (11.57 percent), seed cost (23.29 percent), plant protection (7.11 percent) and irrigation charge (9.19 percent), respectively of the total cost of cultivation. Per hectare cost of cultivation was found of positive trend with farm size.

Estimates of different cost showed that on an average cost $A_{1} / A_{2}, \operatorname{cost} B_{1}$, cost $B_{1}$, cost $C_{1}$, cost $C_{2}$ and cost $C_{3}$ came to $\square 64288.31$, $\square$ 68601.86, $\square$ 78619.86, $\square 52531.47$, $\square$ 84262.80, $\square 92691.29$, respectively.

The average gross income was recorded $\square 191544.33$ and net income came to 105083.49. On medium farms, gross income was highest, which was recorded $\square 192000.00$, followed by margnal farms $\square 191804.33$ and lowest on small farms $\square$ 190829.27, respectively. The net income was highest on marginal farms $\square 105886.69$ followed by medium farms $\square 105604.43$ and small farms $\square$ 103759.37.

On an average family labour income, farm business income and farm investment income were observed to $\square 112942.673, \square 88922.89$ and $\square 84926.61$, respectively. Family labour income was highest on marginal farms followed by medium and small farms, farm investment income was highest on medium farms followed by small farms and marginal farms and farm business income was highest on marginal farms followed by medium farms and small farms. On an average, yield per hectare was estimated 598.57 quintal.

The input output ratio regarding costs $\mathrm{C}_{3}$, $\mathrm{C}_{2}, \mathrm{C}_{1}, \mathrm{~B}_{2}, \mathrm{~B}_{1}$, and $\mathrm{A}_{2} / \mathrm{A}_{1}$ were recorded $1: 2.06,1: 2.27,1 ; 2.57,1: 2.43,1: 2.78$ and 1:2.97, respectively. On the basis of cost $\mathrm{C}_{3}$ input output ratio was highest on medium farms (1:2.11) followed by small farms $(1: 2.08)$ and marginal farms (1:2.01), respectively. I t may be concluded the cost of cultivation on different size group of farm increases with an increase in farm size. But net return per hectare was found of negative trend with farm size. It was because of less increase in yield against the increased input factors at increasing size of farm. 
The production function analysis showed In marginal household the production elasticities of seed, irrigation, plant protection chemicals, fertilizer and labour were 0.01, 0.06, 0.44, 0.24 and 0.63 , respectively. The return to scale in marginal farm was 0.97 which shows decreasing return to scale i.e. marginal farmers were gaining less than what they were spending. The $\mathrm{R}^{2}$ value of marginal household was 0.90 i.e. the considered variable explains 90.00 percent of the variation in depending variable i.e. return from sugarcane. It can be concluded that cost of fertilizer at 5 percent level of significance had significant influence on the returns.

In small household the production elasticity's of seed, irrigation, plant protection chemicals, fertilizer and labour were $0.10,0.20,0.25$, 0.07 and 0.47 , respectively. The return to scale in small farm was 1.09 which shows increasing return to scale i.e. small farmers were gaining more than what they were spending. The $\mathrm{R}^{2}$ value of small household was 0.93 i.e. the considered variable explains 93.00 percent of the variation in depending variable i.e. return from sugarcane. The cost of seed at 5 percent level of significance and cost of irrigation at 1 percent level of significance had significant influence at the returns from sugarcane

In medium household the production elasticity's of seed, irrigation, plant protection chemicals, fertilizer and labour were 0.30, $0.44,0.11,0.23$ and 0.02 , respectively. The return to scale in medium farm was 1.10 which shows increasing return to scale i.e. medium farmers were gaining more than what they were spending. The $\mathrm{R}^{2}$ value of medium household was 0.95 i.e. the considered variable explains 95.00 percent of the variation in depending variable i.e. return from sugarcane. It was found that the cost of seed at 5 percent level of significance and cost of irrigation at 1 percent level of significance had significant influence at the returns from sugarcane.

\section{References}

Keshavaiah, K.V., Palled, Y.B. and Nandihali, B.S. (2013). Economics of sugarcane cultivation under organic and integrated nutrient management practices in Cauvery Command Area.Research Journal of Crop Improvement, 4(2):127-130.

Krishnakant, Tripathi, S.P. and Meena, M.(2015). Cost of cultivation of sugarcane crop in Meerut district of Uttar Pradesh .International Journal of Forestry and Crop Improvement, 6(1): 35-42.

Kumar, H., Bajpai, P.K. and Singh, S.N. (2010). Economic analysis of sugarcane cultivation in different states of India.Indian Journal of Sugarcane Technology. Vol. 25, No. 1/2, pp.97.

Kumar, T., Singh, H.L., Kumar, S. J. and Sachan, S. (2014).Cost and returns of sugarcane production at different sizegroups of farms in district Meerut. (U.P.), India. Annuals of Agri Bio Research, 19(3): 561-565.

Lahoti, S.R., Chole, R.R. and Rathi, N.R. (2010).Constraints in Adoption of Sugarcane Production Technology. Agricultural Research Communication Centre, 30(4): 270-272.

Pal A.K., Katiyar, R., Singh, H.C. and Rajmani (2017). Socio-Economic Profileof Sugarcane Growers in District Moradabad, Uttar Pradesh, India, International Journal of Current Microbiology and Applied Sciences, 6(9): 1212-1229. 
How to cite this article:

Avinash Mishra, R. R. Kushwaha and Praharsh Singh. 2021. A Study on Resource Use Efficiency and Cost and Return of Sugarcane Cultivation in Sultanpur District of Eastern Uttar Pradesh. Int.J.Curr.Microbiol.App.Sci. 10(01): 3255-3261.

doi: https://doi.org/10.20546/ijcmas.2021.1001.379 